\title{
A STUDY OF THE REINFORCEMENT USED BY ENGLISH TEACHER IN 6A CLASS AT SD LAB UNDIKSHA SINGARAJA
}

\author{
Pratiwi, M. B. A \\ English Language Education, Ganesha University of Education, Singaraja \\ Email: bellaanjanip@gmail.com \\ Sudirman \\ English Language Education, Ganesha University of Education, Singaraja \\ Email: sudirman@Undiksha.ac.id \\ Adnyani, L. D. S \\ English Language Education, Ganesha University of Education, Singaraja \\ Email: surya.adnyani@Undiksha.ac.id
}

\begin{abstract}
This study was a descriptive study aimed at describing the components and the implementation of reinforcement used by English teacher in 6A class at SD LAB Undiksha Singaraja. The subjects of this study were an English teacher and 39 students. The data of this study were collected by observation and interview. The result of this study showed that the English teacher in 6A class at SD LAB Undiksha Singaraja used various kinds of reinforcement such as verbal, gestural, contact, and proximity reinforcement. Positive and negative reinforcement were consisted by each of those types. For positive reinforcement, the teacher used "good, very good, well done, good enough, that's right, nice, smiling, nodding head, thumb up, applause, touching the students, standing next to the students, and sitting close with the students". For negative reinforcement, the teacher used "sssst, calling students' name, giving warning, giving explanation, and putting forefinger in front of the lips". Besides, the teacher used four ways in implementing the reinforcement: given with warmth and enthusiastic, emphasized on meaningfulness, given to both group and individual, and given with various types and purposes.
\end{abstract}

Key words: elementary school, reinforcement

\section{INTRODUCTION}

Teacher is an important component in teaching and learning process. The effectiveness of teaching and learning process depends on how the teacher manages the students in the class (Wahyudi, 2013:102). In teaching the students especially for young learners, the teacher also should have a strategy to make the students have willingness to learn and pay attention at the teacher. Padmadewi, Artini, \& Agustini (2017:8) stated that teaching strategy is the way teacher show their creativity in teaching the students. When the teacher shows their creativity in the learning process it will make the learning process become fun and make the students has willingness to learn in the classroom. Reinforcement is a good strategy to build good behavior of students and motivate them to learn.

According to Slavin (in Kinyanjui, Mutisya, \& Nyang'ara, 2015:267), reinforcer is defined as any consequence that strengthens behavior. In addition to keeping behavior under control, reinforcement in the classroom should be used to keep students engaged and motivated to learn. Sanjaya (2006:37) said that the reinforcement process can give positive effect to the students' attitude. It means that an event or stimulus is presented as a consequence of an attitude and the attitude increases. If the students have a good attitude, they will pay attention more to the lesson and be more respectful to the teacher in classroom activity. After the students do good behavior and the teacher gives a reward, the students will feel appreciated and they will repeat the same act later on. In giving reinforcements to the students, the 
teacher can use verbal or nonverbal reinforcements. In giving reinforcements to the students, the teacher can use verbal or nonverbal reinforcements.

According to Peters (2010:1), verbal reinforcement is usually expressed by using words such as compliment, appreciation, and agreement while the nonverbal reinforcement typically expressed by using movement, smile, or provide symbols and things as a sign of appreciation. Reinforcement is really needed in the teaching and learning process especially for young learners because it can develop high motivation of them and they will do their best in classroom activity. By giving reinforcement to the students it can make the students feel appreciated by their teacher. The students will continue the good behavior that they show continually. They will be able to propose their answer and argument. The students will feel confident to speak because the teacher always appreciates the good behavior that students show. Beside, the teacher also gives reinforcement to the students who do bad behavior where the reinforcement make students more interest and pay attention to the teacher and learning process. Furthermore the students will stop their bead behavior. The teacher can gives positive or negative reinforcement to the students it depends on students' act.

Positive reinforcement is given by the teacher when the students do good things and negative reinforcement when the students do misbehavior in the learning activities. According to Diedrich (2010:6), Positive reinforcement is the presentation of reward immediately following a desired behavior intended to make the behavior occur again in the future. The main goals of using positive reinforcements in the learning activity is to encourage the learners to repeat the good act that they have done and that would prove useful for them and also for the class. Beside, negative reinforcement is any stimulus removal which increases the likelihood of particular behavior (Hoque, 2013:13). The effect of negative reinforcements is to remove aversive behavior. In other words, the presence of negative reinforcement aims at decreasing or removing such unpleasant condition so the person being reinforced will change the behavior to be better. From those explanations it can be concluded that positive reinforcement is used to motivate the students to do right thing continuously and negative reinforcement to stop misbehavior and change it to good behavior.

In giving reinforcement to the students, the teacher also should make some variations; the teachers should use different kinds of reinforcement to the students. The teacher gives variation verbal or nonverbal reinforcement in order to make the student not feel bored with the teacher. So it can make the students have higher motivation to learn and build good behavior in the teaching and learning process. If the teacher used monotone reinforcement, the students will feel bored and they may not interest in the learning process anymore. Therefore, the role of the teacher here is very important in giving the students variation of the reinforcements.

Based on the pre observation previously at SD LAB UNDIKSHA Singaraja, it was found that the teacher in 6A class have already used reinforcement in teaching and learning process. The teachers have used reinforcement in the learning process to reinforce students' behavior. This research was conducted at this school because the teachers have already used various kinds of reinforcements in the learning process. To find out the components of reinforcement used by English teacher and how it is implemented in 6A class at SD LAB UNDIKSHA Singaraja were the purposes of the research. The research was conducted descriptively.

\section{METHODS}

In this study, the researcher applied qualitative design. The researcher gathered the data and then drawn the conclusion at the end. The researcher collected the data by observation and recording the components of the reinforcement that are used by English teacher and how are the implementation of the reinforcement used by English teacher in 6A class at SD LAB UNDIKSHA Singaraja. All of the data described and analyzed qualitatively. The subjects of this study were an English teacher and 39 students in $6 \mathrm{~A}$ class. based on the pre-observation before, the teacher in this class already used reinforcement in the teaching and learning process. Therefore this class was selected as the place to conduct the research.

For the method of data collection, the researcher used four methods namely: observation, interview, video recording, and also note taking. In this research the researcher used observation to observe the components of the reinforcement used by English teacher and how the implementations of the reinforcement were used by English teacher in 6A class at SD LAB UNDIKSHA Singaraja. In interview, the researcher collected the data and information by giving the teacher several questions about 
what components of the reinforcement used by English teacher and how the implementations of the reinforcement were used by English teacher in 6A class at SD LAB UNDIKSHA Singaraja. Video recording used to record all of the activities that done by the teacher and the students in the learning process. Note taking was used to help the researcher remind important things in the field. This instrument was also used to write kinds of reinforcement that occurred in the classroom during teaching and learning process.

There were several processes in data analysis such as data collection, data reduction, data display, and conclusion drawing. Data collection, in this study the data of two research questions were collected through observation and interview. In data reduction, the researchers chose the basic and important data. In this study the researcher collected the data through analysis, observation and interview. The researcher reduced the data and chose the important data which had relation with the problem that should be solved. In data display the data were in the form of table or essay. The analysis was about the use of reinforcement in 6A class at SD LAB UNDIKSHA Singaraja. The data was also in the form of identification of reinforcement used in the classroom which was based on the focus of the research. In this research, the researcher observed how the teachers implement the use of reinforcement in 6A class at SD LAB UNDIKSHA Singaraja. In conclusion drawing/verification, the researcher drew a conclusion or verification, the researcher considered about the data analysis and assessed the appropriateness of the result of data analysis with the question and the purposes of the research.

\section{FINDING AND DISCUSSION Finding}

From the data gained in this study, it can be concluded that there are some reinforcements used by the teacher in teaching. The following tables show the detail of the findings.

Table 1 Components of Verbal Reinforcement Used at 6A Class in SD LAB UNDIKSHA Singaraja

\begin{tabular}{|c|c|c|c|}
\hline $\begin{array}{c}\text { Components of } \\
\text { Verbal } \\
\text { Reinforcement }\end{array}$ & Frequency & $\begin{array}{l}\text { Percentage } \\
\quad(\%)\end{array}$ & Example Context of Occurrence \\
\hline Good & 16 & $11,3 \%$ & $\begin{array}{l}\text { It was given when the students could answer } \\
\text { teacher's question correctly. }\end{array}$ \\
\hline Very good & 20 & $14,1 \%$ & $\begin{array}{l}\text { It was given when the students could answer } \\
\text { teacher's question correctly and present their } \\
\text { work perfectly. }\end{array}$ \\
\hline Well done & 4 & $2,8 \%$ & $\begin{array}{l}\text { It was given when the students could answer } \\
\text { teacher's question correctly }\end{array}$ \\
\hline Good enough & 1 & $0,7 \%$ & $\begin{array}{l}\text { When the students could answer but not } \\
\text { completely correct. }\end{array}$ \\
\hline Great & 5 & $3,5 \%$ & $\begin{array}{l}\text { When the students can answer quickly and } \\
\text { correctly }\end{array}$ \\
\hline That's right & 10 & $7 \%$ & $\begin{array}{l}\text { It was given when the students can answer } \\
\text { teacher's question correctly }\end{array}$ \\
\hline Nice & 8 & $5,6 \%$ & $\begin{array}{l}\text { When the students were active in the learning } \\
\text { process, such as can answer the question. }\end{array}$ \\
\hline Sssstt & 2 & $1,4 \%$ & It was given when the students were too noisy \\
\hline $\begin{array}{l}\text { Calling students' } \\
\text { name }\end{array}$ & 5 & $3,5 \%$ & When the student made noise in the classroom \\
\hline Giving warning & 6 & $4,2 \%$ & $\begin{array}{l}\text { When the students did not pay attention to the } \\
\text { teacher's explanation }\end{array}$ \\
\hline Giving explanation & 2 & $1,4 \%$ & When the students did not pay attention \\
\hline Total & 79 & $55,5 \%$ & \\
\hline
\end{tabular}


From the table above, it was clearly showed that the teacher in 6A class at SD LAB UNDIKSHA Singaraja used 11 kinds of verbal reinforcements such as good $(11,3 \%)$, very good $(14,1 \%)$ well done $(2,8)$, good enough $(0,7 \%)$, great $(3,5 \%)$, that's right $(7 \%)$, nice $(5,6 \%)$, "sssttt" $(1,4)$, calling students' name $(3,5 \%)$, giving warning $(4,2 \%)$, and also giving explanation $(1,4 \%)$. Those components also covered positive and negative reinforcement. The most component that used by the teacher were very $\operatorname{good}(14,1 \%)$.

Table 2 Components of Gestural reinforcement Used in 6A class at SD LAB UNDIKSHA Singaraja

\begin{tabular}{|c|c|c|c|}
\hline $\begin{array}{l}\text { Components of } \\
\text { gestural } \\
\text { reinforcements }\end{array}$ & Frequency & Percentage & Context \\
\hline Applause & 10 & $7 \%$ & $\begin{array}{l}\text { It was given when the students presented their } \\
\text { work perfectly. Answered teacher's question } \\
\text { completely and correctly. }\end{array}$ \\
\hline Smile & 7 & $4,9 \%$ & $\begin{array}{l}\text { It was given when the students did something } \\
\text { good and also when they answered teacher's } \\
\text { question and finished the task, etc. }\end{array}$ \\
\hline Nodding head & 25 & $17,7 \%$ & $\begin{array}{l}\text { It was given when the students' answer was } \\
\text { correct }\end{array}$ \\
\hline Thumbs up & 7 & $4,9 \%$ & $\begin{array}{l}\text { When the students correctly answered teacher's } \\
\text { questions }\end{array}$ \\
\hline $\begin{array}{l}\text { Fore finger in front } \\
\text { of the lips }\end{array}$ & 2 & $1,4 \%$ & It was given to make students silent. \\
\hline Total & 50 & $35,9 \%$ & \\
\hline
\end{tabular}

From the table above, it was clearly showed that the teacher in 6A class at SD LAB UNDIKSHA Singaraja used 5 kinds of gestural reinforcement such as applause (7\%), smile (4,9\%), nodding head $(17,7 \%)$, thumb up $(1,4 \%)$. Those components also covered positive and negative reinforcement. the most component used by the teacher were nodding head $(17,7 \%)$.

Table 3 Components of Contact Reinforcement Used at 6A Class in SD LAB UNDIKSHA Singaraja

\begin{tabular}{llll}
\hline $\begin{array}{l}\text { Components of } \\
\text { contact } \\
\text { reinforcement }\end{array}$ & Frequency & $\begin{array}{l}\text { Percentage } \\
(\%)\end{array}$ & Context \\
\hline Touch the students & 3 & $2,1 \%$ & $\begin{array}{l}\text { When the students did something good in the } \\
\text { learning process }\end{array}$ \\
Total & 3 & $2,1 \%$ & \\
\hline
\end{tabular}

From the table above, it was clearly showed that the teacher in 6A class at SD LAB UNDIKSHA Singaraja used only one kind of contact reinforcement such as touching the students $(2,1 \%)$.

Table 4 Components of Proximity Reinforcement used in 6A class at SD LAB UNDIKSHA Singaraja

\begin{tabular}{lccl}
\hline $\begin{array}{l}\text { Components of Frequency } \\
\text { proximity } \\
\text { reinforcement }\end{array}$ & $\begin{array}{l}\text { Percentage } \\
(\%)\end{array}$ & Context \\
\hline $\begin{array}{l}\text { Standing beside the } \\
\text { students }\end{array}$ & 5 & $3,5 \%$ & $\begin{array}{l}\text { When the teacher wanted to approach the } \\
\text { students by asking question or answering the } \\
\text { students' question. }\end{array}$ \\
$\begin{array}{l}\text { Sitting close with } \\
\text { the students }\end{array}$ & 3 & $2.1 \%$ & $\begin{array}{l}\text { When the teacher wanted to give explanation to } \\
\text { the students who were still confused with the }\end{array}$ \\
\hline
\end{tabular}


teacher's task or instruction.

Total $\quad 8 \quad 5,6 \%$

From the table above, it was clearly showed that the teacher in 6A class at SD LAB UNDIKSHA Singaraja used 2 kinds of proximity reinforcement like standing beside the students $(3,5 \%)$ and also sitting close with the students $(2,1 \%)$. The most component used were standing beside the students $(3,5 \%)$.

Table 5 How the Reinforcement is implemented in 6A Class at SD LAB UNDIKSHA Singaraja

\begin{tabular}{llrl}
\hline No & The way & Type of Reinforcement used \\
\hline 1 & Reinforcement was given with & - & Verbal reinforcement \\
& warmth and enthusiasm & - Gestural reinforcement \\
2 & Reinforcement was emphasized & - Verbal reinforcement \\
& $\begin{array}{l}\text { on meaningfulness } \\
3\end{array}$ & - Reinforcement was given to both & - Vestural reinforcement \\
& $\begin{array}{l}\text { groups of students as well as to } \\
\text { individual students }\end{array}$ & - Contact reinforcement \\
4 & Reinforcement was given with & - Proximity reinforcement \\
variation types and purposes & - Verbal reinforcement \\
\hline
\end{tabular}

The teacher used various ways in implementing reinforcements to the students. Based on the table above the there were four ways in implementing reinforcement. First, reinforcement was given with warmth and enthusiasm for verbal and gestural reinforcement. Second reinforcement was emphasized on meaningfulness for verbal and gestural reinforcement. Third, reinforcement was given to group and individual for verbal, contact, and proximity reinforcement, and the last reinforcement was given with variation types and purposes for verbal and gestural reinforcement.

\section{Discussion}

The finding showed that the English teacher in 6A class at SD LAB UNDIKSHA Singaraja used reinforcement strategy in the learning process. The teacher used this kind of strategy to improve students' good behavior, maintain their good behavior in the future and remove their bad behavior. Based on the finding, there were four kinds of reinforcement used by English teacher in 6A class at SD LAB UNDIKSHA Singaraja. The reinforcements used by the teacher were verbal, gestural, contact, and proximity reinforcement. After the researcher explained about the components used in 6A class at SD LAB UNDIKSHA Singaraja, the findings were classified again into positive and negative reinforcement. According to Djamarah (2005:120), there are some components of reinforcement namely verbal, gestural, contact, proximity, and token reinforcement. The teacher in 6A class at SD LAB UNDIKSHA Singaraja only used four components of reinforcement namely, verbal, gestural, contact, and also proximity reinforcement. Based on the finding, the English teacher used some kinds of verbal reinforcement, such as 'good', 'very good', 'well done', 'great', 'that's right', 'good enough', 'nice'. Those are the positive verbal reinforcement given by the teacher. The frequently used reinforcement by the teacher was verbal positive reinforcement such as 'good' and 'very good'. All of the verbal reinforcement above could improve students' spirit and motivation in the learning process. In the negative verbal reinforcement, the teacher used 'sssstt', calling name, giving warning, and also giving explanation. Negative verbal reinforcement that is frequently used by the teacher was calling name of the students. It shows that in this study the researcher found other type of verbal reinforcement. All the reinforcement was given by the teacher to remove the unwanted behavior of the students. By giving those kinds of negative verbal reinforcement, the students realized their mistake and could change their negative behavior into positive behavior. This finding has similarities with the finding by Manzoor, Ahmed, and Gill (2014), they found that the children become more motivated towards learning English language when they were positively reinforced by motivational expression such as well done, keep it up, excellent, good, very good, I am proud of you, and you are good students. They also found that 
motivational reinforcement is the best source for enhancing students' motivation in learning and bringing good changes in students' behavior. While the differences are kinds of verbal reinforcement used by the teacher and also in Manzoor et al. (2014), the researcher only described about the verbal reinforcement while in this research, the researcher described about verbal and non-verbal reinforcement and how the reinforcement are implemented. This finding also similar with a research conducted by Bhutto (2011), he found that the students of treatment group who were taught through reinforcement-based teaching achieved better learning outcome. The type of reinforcement used in his study was verbal and nonverbal reinforcement. Besides, the differences are the teacher always gives reinforcement using English while in this research, the teacher sometimes combined English and also Indonesian in giving reinforcement to the students. Gestural reinforcements used by English teacher in 6A class at SD LAB UNDIKSHA Singaraja were smile, nodding head, thumbs up, clap hands, and forefinger in front of mouth. All of the gestural reinforcements were given to make the students improve their desired behavior. Gestural reinforcement such as smile could make the students felt comfortable. It also made the students would not be afraid in expressing anything to the teacher. Hence, the students would be more active in the learning activity. Thumbs up could make the students felt proud of their work, the students would try to show their good work again in the future. Nodding head was given when the students could answer the question correctly, and clapping hands was given when the students performed perfectly in front of the class. After getting applause from the teacher, the students would look happy because their works were really given high appreciation by the teacher. While the negative gestural reinforcement used by the teacher in $6 \mathrm{~A}$ class at SD LAB UNDIKSHA Singaraja was putting forefinger in front of the lips. That kind of reinforcement was given to remove undesired behavior of the students. For the example when a student made noise in the classroom, the teacher gave gestural reinforcement such as putting forefinger in the lips while saying 'sssst'. It was given to make the students knew that their act or behavior were not good or not appropriate. In giving gestural reinforcement, the teacher usually combined with the verbal reinforcement. According to Djamarah (2005:120), there are some types of gestural reinforcement such as nodding head, thumbs up, and applause. While in this study the researcher found new types of gestural reinforcement such as smile and put forefinger in front of the lips. The teacher in 6A class at SD LAB UNDIKSHA Singaraja used contact reinforcement, such as touching the students. It indicates that the teacher wanted to create close relationship to the students, it also made the students felt comfortable and did not afraid with the teacher. Giving touch was given to the students when the students showed good behavior in the learning process. It also happened when the students performed well. The teacher gave verbal reinforcement to the students while touching their hand. After getting that kind of reinforcement the students felt happy and proud. Besides, the teacher also used proximity reinforcement in the learning process such as standing next to the students and also sitting close to the students. It was happened when the teacher asked the student to work in group. The teacher controlled every group and asked every group. If there was a question, the students could ask directly to the teacher. The teacher would explain by sitting close to the students or standing next to them. It made the relationship between teacher and the students closer. The students felt that the teacher cared of them, hence the students would not be afraid asking anything to the teacher.

According to Usman (2013:82), there are 4 ways to implement reinforcement while teaching in class. Those reinforcements are given with warmth and enthusiast, the principle of meaningfulness, and reinforcement for group of as well as individual, and variations in the use of reinforcement. All of the way which was intended to give the reinforcement in the classroom could be given appropriately and meaningfully to the students. Students could be motivated and understood the reinforcement provided by the teacher. The teacher in 6A class at SD LAB UNDIKSHA Singaraja used all of the principle in implementing reinforcement.

Reinforcement is given with warmth and enthusiast, according to Usman (2013:82) who states that giving reinforcement should be enthusiastic and the teacher should pay attention to the students when giving reinforcement. Hence, the reinforcement can be effective to students. The teacher in $6 \mathrm{~A}$ class at SD LAB UNDIKSHA Singaraja provided reinforcement by looking at the intended students, smiling, and also saying verbal reinforcement with enthusiastic way. When the teacher gave contact reinforcement in the form of touching the students shoulder, the teacher also gave with warmth in order to make the students felt comfortable and appreciated. As well as giving verbal reinforcement to the students, the teacher also said with high enthusiasm to make the students become excited. When the 
teacher gave applause and thumbs up to the students, it was followed with smile and even laughs. The teacher in 6A class at SD LAB UNDIKSHA Singaraja had done the reinforcement in warmth and enthusiastic way. It also could be seen from the students' response when receiving reinforcement they always looked happy.

Next one is the principle of meaningfulness. In order to make the reinforcement given is meaningful for students' behavior, the teacher uses reinforcement based on the students' behavior level. The most visible reinforcement which has a level of meaning is verbal reinforcement. The teacher in 6a class at SD LAB UNDIKSHA Singaraja used a lot of reinforcements in the form of praise to the students such as, good, very good, good enough. It was used to differentiate the level of students' behavior. If the students could answer the teacher's question correctly the teacher would say 'good', if the students presented their work perfectly the teacher would say very good, if the answer of the students were not complete the teacher would say 'good enough'. As well as gestural reinforcement, the teacher would not give excessive reinforcement to the students. For the example if the students did something that could be proud of, the teacher would give applause. Not all of the students' behavior would be applauded.

Reinforcement was given to both groups of students as well as to individual students. The teacher in 6A class always gave reinforcement to both group and individual because the students have already tried to do something in their group or individually. The teacher always appreciated students' work in individual and group. Hence, all would be appreciated by the teacher by giving them reinforcement. The last is variations in the use of reinforcement. Variation in giving reinforcement is very important in order to make the students felt comfortable and avoiding boredom. The teacher in 6a class at SD LAB UNDIKSHA Singaraja combined verbal and gestural reinforcement to the students. Besides, the meaning of reinforcement would be more conveyed well, it would be clearer by combining reinforcement. The teacher said that it aimed to make the reinforcement more effective and make the students more excited because more than one type reinforcement is better. In the terms of varying the provision of reinforcement, the teacher had already used a lot of variation in each type. It can be seen from many types of reinforcement of each component that has been described in findings.

\section{CONCLUSION}

The result showed that the English teacher in 6A class at SD LAB UNDIKSHA Singaraja used reinforcement as strategy in teaching the students in order to make the students improve their good behavior and decrease their undesired behavior. There were two kinds of reinforcement used by the teacher in the classroom activity. The components of reinforcement are also classified into more specific component namely verbal, gestural, contact, and proximity reinforcement. Every component consists of positive and negative reinforcement.

In the positive verbal reinforcement, the teacher in 6a class at SD LAB UNDIKSHA Singaraja used 'good, very good, well done, great, good enough, that's right, and nice. While in positive gestural reinforcement, the teacher used smile, nodding hands, applause, and thumbs up. Those kinds of reinforcement could make the classroom atmosphere more enthusiastic and fun. Contact reinforcement used by the teacher was only touching the student hand. It could build close relationship between the teacher and the students. In the proximity reinforcements, the teacher used sitting-close to the students and standing next to the students. It also could make the relationship between the teacher and the student closer. Besides, the students would not be afraid with the teacher and feel comfortable with the teacher.

For the negative verbal reinforcement, the teacher used 'sssst', calling students' name, giving warning, and also giving explanation to the students. Then negative gestural reinforcement used by the teacher was putting forefinger in front of the lips. Those reinforcements were given in order to eliminate the undesired behavior or attitudes of the students and make them increase their good behavior later on. There are four principles to implement reinforcement namely, giving warm and enthusiastic reinforcement, principal of meaningfulness, providing individual or group reinforcement, and giving variation of reinforcement. The teacher in 6A class at SD LAB UNDIKSHA Singaraja used all of those principles in implementing the reinforcement to the students. In relation to the conclusion above, the researcher would like to propose some suggestions, firs the teacher should have good understanding in classroom management because the skill of giving reinforcement strategy is an important part of classroom management. If the teachers are able to create good classroom management, the reinforcement strategies will be implemented well. Second, the teacher should understand the ways in 
which how to make the reinforcements become effective. Based on the result of the study, it was found 4 ways in giving reinforcement to the students. Hopefully, this research can be beneficial for the teacher and the other researcher in terms of the types of reinforcement and how to implement the reinforcements in the classroom.

\section{REFERENCES}

Bhutto, M. I. (2011). Effects of Social Reinforcers on Students'Learning Outcomes at Secondary School Level. International Journal of Academic Research in Business and Social Sciences, 1(2), 71.

Diedrich, J. L. (2010). Motivating students using positive reinforcement.education and human development master's theses. State University of New York. Brockport: Digital Commonns.

Djamarah, S. (2005). Guru dan anak didik dalam interaksi anak didik. Jakarta: PT. Rineka Cipta.

Hoque, R. (2013). Effect of Reinforcement on Teaching-Learning Process. IOSR Journal Of Humanities And Social Science, 7(1), 13-16.

Kinyanjui, M. W., Aloka, P. J., Mutisya, S. K., Ndeke, F. N., \& Nyang'ara, N. M. (2015). Classroom Reinforcement Schedules and Their Effectiveness in Selected Kenyan Primary Schools. Journal of Educational and Social Research, 5(3), 41.

Manzoor, F., Ahmed, M., \& Gill, B. R. (2014). Use of motivational expressions as positive reinforcement in learning English at primary level in rural areas of Pakistan. British Journal of English Linguistics, 2(3), 30-42.

Padmadewi, N. N., Artini, L. P., Agustini, D. E. (2017). Micro Teaching.Yograkarta: Raja Gravindo.

Peters, L. C. (2010). Reinforcement in the classroom improves student motivation and performance. Innovations and Perspectives.

Sanjaya, W. (2006). Strategi Pembelajaran Berorientasi Standar Proses Pendidikan. Jakarta: Kencana Prenada Media Group.

Usman, H. (2013). Manajemen: Teori, PraktikdanRisetPendidikan -Ed.4, Cet.1-.Jakarta: BumiAksara.

Wahyudi, D. (2013). An AnalysisofReinforcement Implemented by English Teachers at Sman 1 Kecamatan V Koto Kampung Dalam Padang Pariaman Regency. English Language Teaching (ELT), 1(2). (101-107). 